\title{
Penggunaan Digital Payment Syariah Pada Masyarakat Di Kota Palembang: Pendekatan Teori Technology Acceptance Model (TAM) pada Layanan Syariah LinkAja
}

\author{
Uswatun Hasanah $^{1 *}$, M Rusydi ${ }^{1}$, Candra Zaky Maulana ${ }^{1}$, \\ Maftukhatushalikhah $^{1}$, Peny Cahaya Azwari ${ }^{1}$ \\ ${ }^{1}$ UIN Raden Fatah Palembang, Indonesia
}

\begin{abstract}
Abstrak: Penelitian ini bertujuan untuk mengetahui bagaimana teknologi berupa layanan syariah linkaja dapat diterima pada kalangan masyarakat di kota Palembang. Kerangka pemikiran telah dikembangkan berdasarkan Technology Acceptance Model (TAM) dengan metode penelitian kuantitatif beruapa perangkat SmartPLS. Hasil penelitian menyatakan bahwa perceived ease of use dan perceived usefulness berpengaruh positif dan signifikan terhadap actual system use, perceived ease of use berpengaruh positif dan signifikan terhadap minat menggunakan, perceived usefulness tidak berpengaruh terhadap minat menggunakan, minat menggunakan berpengaruh positif dan signifikan terhadap actual system use, perceived ease of use berpengaruh positif dan signifikan terhadap actual system use melalui minat menggunakan, dan perceived usefulness tidak berpengaruh terhadap actual system use melalui minat menggunakan.
\end{abstract}

Kata Kunci: layanan syariah LinkAja, TAM, SmartPLS

\begin{abstract}
This study aims to find out how technology in the form of linkaja sharia services can be accepted among the people in the city of Palembang. The framework has been developed based on the Technology Acceptance Model (TAM) with quantitative research methods in the form of SmartPLS devices. The results of the study stated that perceived ease of use and perceived usefulness had a positive and significant effect on actual system use, perceived ease of use had a positive and significant effect on interest in using, perceived usefulness had no effect on interest in using, interest in using had a positive and significant effect on actual system use. , perceived ease of use has a positive and significant effect on actual system use through interest in using, and perceived usefulness has no effect on actual system use through interest in using.
\end{abstract}

Keywords: Sharia services LinkAja, TAM, SmartPLS

\section{Pendahuluan}

Penelitian ini dilatarbelakangi oleh adanya suatu fenomena menarik yaitu di tengah dominasi GoPay, Ovo, dan Dana, ada satu layanan yang cukup potensial untuk tumbuh yakni LinkAja. LinkAja dirintis oleh gabungan BUMN yang diantaranya adalah empat bank besar yakni
Mandiri, BNI, BRI, dan BTN. Maka tidak mengherankan jika payment yang dikelola oleh PT. Fintek Karya Nusantara (Finarya) ini memiliki dukungan permodalan yang cukup besar sehingga memiliki kesempatan untuk mampu bersaing dengan layanan payment lainnya.

\footnotetext{
* Corresponding Author: Uswatun Hasanah (uswatunhas95@gmail.com). UIN Raden Fatah Palembang, Indonesia
} 
Berdasarkan riset yang dilakukan iPrice dan App Annie dengan rentan waktu Kuartal IV 2017 sampai dengan kuartal II 2019 menunjukan bahwa LinkAja menempati posisi empat besar layanan payment di Indonesia. LinkAja berada di bawah Gopay, Ovo dan Dana. Posisi LinkAja turun dari peringkat dua pada kuartal II 2019. Pada akhir tahun 2019 kemarin, LinkAja menjalankan strategi yang bisa dibilang cukup unik yakni dengan meluncurkan layanan LinkAja Syariah. Layanan tersebut merupakan dompet digital berbasis syariah pertama di Indonesia. Layanan ini bisa dibilang cukup unik karena pesaing lain seperti Gopay, Ovo, dan Dana belum menyasar segmentasi pasar keungan syariah seperti yang dilakukan oleh LinkAja. LinkAja juga telah mengantongi setifikasi penyesuaian syariah dari Dewan Syariah Nasional Majelis Ulama Indonesia (DSN MUI).

Layanan Syariah LinkAja telah memiliki sekitar 1,8 juta pengguna sampai akhir Januari 2021. Jumlah itu diyakini bakal terus meningkat seiring kolaborasi bersama mitra strategis. Berdasarkan catatan Investor Daily, per 13 Januari 2021 layanan syariah LinkAja memiliki 1,6 juta pengguna. Jumlah itu meningkat menjadi 1,8 juta pengguna pada 28 Januari 2021. Pengguna akan terus meningkat sejalan komitmen kolaborasi dari beberapa partner strategis, seperti pemerintah daerah dan institusi lainnya demi mencapai perluasan ekosistem digital syariah di seluruh Indonesia (Komite Ekonomi Nasional dan Keuangan Syariah, 2021)

LinkAja mulai mengembangkan uang elektronik berbasis syariah di Kota Palembang melalui Layanan Syariah LinkAja. Dalam pengembangan layanan syariah tersebut, LinkAja telah menggandeng sejumlah merchant lokal hingga instansi keagamaan di Kota Palembang.
Adapun layanan syariah LinkAja dapat digunakan di merchant lokal da ritel modern Palembang, seperti JM Group, Diamond, Trona Group, Linda Kosmetik Atmo, Dapur Mutiara, dan 212 Mart. Bahkan warga Palembang juga dapat bertransaksi di kuliner ternama, seperti Kenten Street, Pempek Candy, Pempek Beringin, hingga membeli kebutuhan pokok di pasar tradisional, yakni Pasar 16 Ilir, Cinde, dan Pasar Gubah.

Selain itu, layanan syariah LinkAja dapat digunakan untuk pembayaran transportasi publik, seperti LRT Sumsel, dan pembayaran rumah sakit (Sumeks, 2021).

Ada salah satu teori yang sangat signifikan dalam memprediksi penerimaan seseorang terhadap teknologi informasi yang berkaitan dengan penggunaan yaitu teori Technologi Acceptance Model (TAM). Teori TAM merupakan salah satu jenis dari model sistem informasi keprilakuan yang bertujuan untuk menjelaskan bagaimana minat pengguna teknologi dalam menerima dan menggunakan teknologi tersebut (Davis, 1989).

Pada model TAM tersebut terdapat dua konstruk utama yaitu Perceived Ease of Use (persepsi kemudahan penggunaan) dan Perceived Usefulness (persepsi kebergunaan). Terdapat konstruk Attitude Towards Using atau sikap dalam menggunakan juga dalam model TAM yang dapat digunakan untuk memprediksi minat, tetapi konstruk ini masih jarang digunakan (Budiastuti \& Muid, 2020).

Menurut Davis, perceived ease of use adalah suatu keadaan dimana seseorang percaya bahwa dengan menggunakan sistem/teknologi tersebut tidak diperlukan usaha apapun. Menurut Adam, Nelson dan Told perceived usefulness merupakan suatu keadaan dimana seseorang percaya terhadap penggunaan sistem/teknologi yang dapat 
memberikan manfaat bagi penggunanya (Muflihhadi \& Rubiyanti, 2016).

Minat menggunakan merupakan tingkat keinginan seberapa kuat seseorang untuk menggunakan/melakukan perilaku tertentu, atau rencana seseorang secara sadar untuk melakukan atau tidak melakukan sesuatu di waktu yang akan datang yang telah ditentukan sebelumnya (Permana, 2018).

Dari fenomena di atas, dimana pengguna layanan syariah linkaja mengalami kenaikan jumlah pengguna yang pesat ini menjadi fenomena yang menarik, mengingat bahwa layanan syariah linkaja merupakan payment yang baru diluncurkan.

\section{Metode Penelitian}

Jenis data yang digunakan dalam penelitian ini adalah jenis data kuantitatif. Jumlah responden sebanyak 340 orang tersebut dianggap sudah refresentatif karena sudah lebih besar dari batas minimal sampel. Dalam penelitian ini digunakan skala Likert. Pengukuran masing-masing variabel menggunakan five-point likert scale, sangat tidak setuju (skala=1), tidak setuju (skala=2), netral (skala=3), setuju (skala=4), sangat setuju (skala=5). Insrumen Penelitian yang digunakan adalah Uji Validitas melalui program SmartPLS, Uji Reliabilitas, Uji Outer Model, Analisis Inner Model, Uji Hipotesis melalui bootstrapping.

\section{Hasil dan Pembahasan}

\section{Uji Validitas}

Validitas indikator dilihat dari nilai Loading Faktor (LF) berdasarkan instruksi. Sesuai aturan (rule of thumb), nilai LF indikator $\geq 0,7$ dikatakan valid. Namun demikian, dalam pengembangan model atau indikator baru, nilai LF antara 0,5-0,6 masih dapat diterima (Yamin dan Kurniawan,
2011:202) dan nilai AVE (Average Variance Extracted/AVE). Nilai Loading Factor $>0,5$, nilai AVE dengan tarif signifikan $>0,50$. Jika nilai Loading Factor $>0,5$ dan nilai AVE $>0,50$, maka dapat dikatakan valid.

Secara rinci nilai loading factor dapat dilihat pada tabel 1:

Tabel 1. Loading Factor Model Final

\begin{tabular}{|l|c|c|c|c|}
\hline & $\begin{array}{c}\text { ASU } \\
\text { (Y) }\end{array}$ & $\begin{array}{c}\text { PEoU } \\
\text { (X1) }\end{array}$ & $\begin{array}{c}\text { MM } \\
\text { (M) }\end{array}$ & $\begin{array}{c}\text { PU } \\
\text { (X2) }\end{array}$ \\
\hline MM 1.1 & & & 0,543 & \\
\hline MM 2.1 & & & 0,665 & \\
\hline MM 3.1 & & & 0,658 & \\
\hline PU 1.1 & & & & 0,639 \\
\hline PU 3.1 & & & & 0,669 \\
\hline PU 4.2 & & & & 0,730 \\
\hline PU 5.2 & & & & 0,548 \\
\hline PEoU 1.1 & & 0,751 & & \\
\hline PEoU 1.2 & & 0.798 & & \\
\hline ASU 1.1 & 0,683 & & & \\
\hline ASU 3.2 & 0,632 & & & \\
\hline ASU 4.1 & 0,666 & & & \\
\hline
\end{tabular}

Tabel 1 di atas menunjukan bahwa semua loading factor memiliki nilai lebih dari 0,5, sehingga dapat dikatakan sudah memenuhi convergent validity.

Tabel 2. Hasil Pemeriksaan Validitas Kontruk Berdasarkan AVE

\begin{tabular}{|c|c|}
\hline & $\begin{array}{c}\text { Averange Variance } \\
\text { Extracte (AVE) }\end{array}$ \\
\hline Actual System Use (Y) & 0,606 \\
\hline Minat Menggunakan (M) & 0,605 \\
\hline Perceived Easy of Use (X1) & 0,502 \\
\hline Perceived Usefulness (Y) & 0,565 \\
\hline
\end{tabular}

Sumber: Data Olahan SmartPLS

Dari tabel 2 di atas menunjukan bahwa semua kontruk berdasarkan AVE memiliki nilai lebih dari 0,5, sehingga dapat dikatakan sudah memenuhi convergent validity. 


\section{Hasil Uji Reliabilitas}

Uji reliabilitas digunakan untuk menguji sejauh mana kendala suatu alat pengujian untuk dapat digunakan lagi untuk peneliti yang sama. Evaluasi terhadap nilai reliabilitas konstruk diukur dengan nilai Composite Reliability. Nilai Composite Reliability semua kontruk harus $\geq 0,7$.

Tabel 3. Hasil Pemeriksaan Reliabilitas Kontruk Berdasarkan Composite Reliability

\begin{tabular}{|c|c|}
\hline & $\begin{array}{c}\text { Composite } \\
\text { Reliability }\end{array}$ \\
\hline Actual System Use (Y) & 0,754 \\
\hline Minat Menggunakan (M) & 0,747 \\
\hline Perceived Easy of Use (X1) & 0,750 \\
\hline Perceived Usefulness (Y) & 0,719 \\
\hline
\end{tabular}

Sumber: Data Olahan SmartPLS

Dari tabel di atas menunjukan bahwa semua kontruk berdasarkan Composite Reliability memiliki nilai lebih dari 0,7 sehingga dapat dikatakan indikator konsisten dalam mengukur konstruknya.

\section{Analisis Outer Model}

Tahap dalam menilai outer model yaitu dapat dilihat melalui nilai outer loading di outer model. Pengolahan data dengan SmartPLS menunjukan bahwa nilai loading factor pada model awal telah memenuhi convergent validity. Suatu data dikatakan convergent validity jika ditunjukan dengan keseluruhan indikator yang memiliki nilai loading factor > 0,4 dan sebaliknya apabila keseluruhan nilai loading factor $<0,4$ maka tidak memenuhi convergent validity. Gambar 4.5 menunjukan analisis outer model partial least square sebagai berikut:
Gambar 1. Model Partial Least Square (PLS)

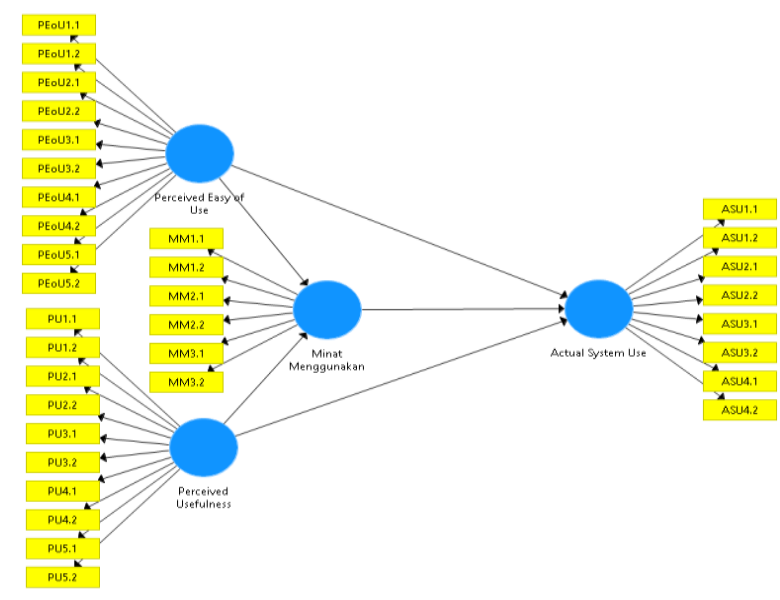

Sumber: Ouput SmartPLS, 2021

Gambar 2. Uji Outer Model Partial Least Square (PLS)

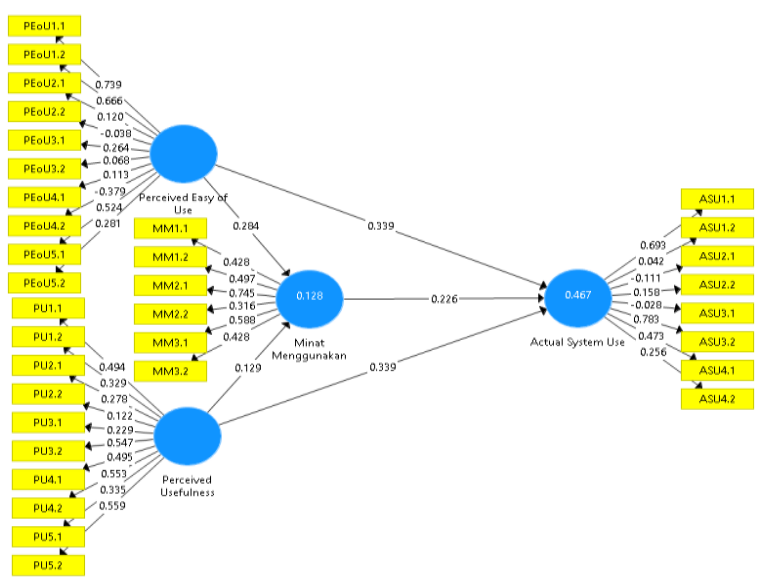

Sumber: Ouput SmartPLS, 2021

Berdasarkan output koefisien jakur pada gambar 2 tahap dalam menilai outer model yaitu dapat dilihat melalui nilai outer loading di outer model. Pengolahan data dengan SmartPLS menunjukan bahwa nilai loading factor pada model awal telah memenuhi convergent validity. Suatu data dikatakan convergent validity jika ditunjukan dengan keseluruhan indikator yang memiliki nilai loading factor > 0,4 dan sebaliknya apabila keseluruhan nilai loading factor $<0,4$ maka tidak memenuhi convergent validity didrop dari diagram penelitian selanjutnya. Sehingga pada diagram 
PEou 2.1, PEou 2.2, PEou 3.1, PEou 3.2, PEou 4.1, PEou 4.2, PEou 5.1, PEou 5.2, PU 1.1, PU 1.2, PU 2.1, PU 2.2, PU 3.1, PU 3.2, PU 4.1, PU 5.1, MM 1.1, MM 1.2, MM 2.2, MM 3.2, ASU 1.2, ASU 2.1, ASU 2.2, ASU 3.1, ASU 4.1, ASU 4.2 didrop dari diagram penelitian selanjutnya, seperti pada gambar dibawah ini.

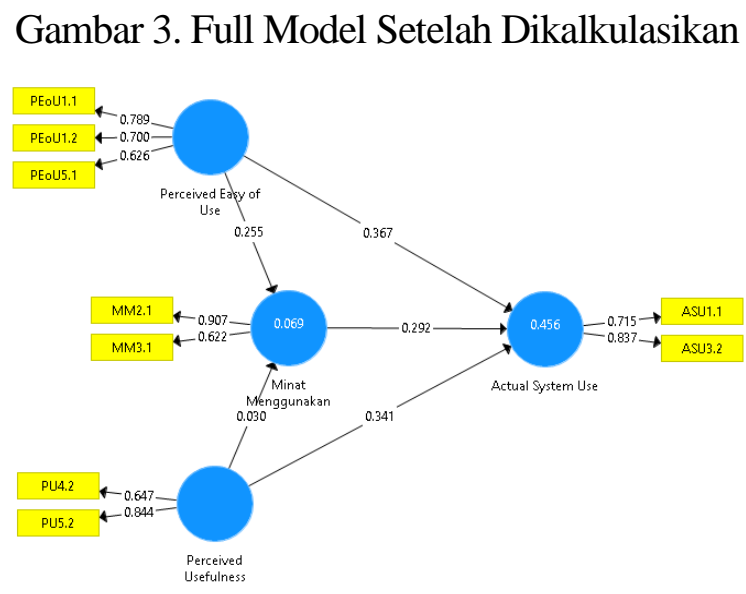

Sumber: Output SmartPLS, 2021

Pada tahap ini dapat dilihat seluruh data loading factor memiliki nilai lebih besar dari 0,7 dan 0,5 , sehingga data tersebut dinyatakan valid dan siap digunakan.

\section{Analisis Inner Model}

Model struktural dievaluasi dengan menggunakan koefisien determinan (Uji R2) dan koefisien path atau t-value. Nilai R2 digunakan untuk mengukur tingkat variasi perubahan variabel independen terhadap variabel dependen. Semakin tinggi nilai R2 berarti semakin baik model prediksi dari model penelitian yang diajukan. Namun, R2 bukanlah parameter absolut dalam mengukur ketepatan model prediksi karena dasar hubungan teoritis adalah parameter yang paling utama untuk menjelaskan hubungan kausalitas tersebut.
Tabel 4 menunjukan uji $R$-square sebagai berikut:

Tabel 4. Nilai $R$-square $\left(\mathrm{R}^{2}\right)$

\begin{tabular}{|l|c|}
\hline & R-square, \\
\hline Actual System Use & 0,456 \\
\hline Minat Menggunakan & 0,069 \\
\hline
\end{tabular}

Sumber: Data Olahan SmartPLS, 2021

Tabel 4 menunjukan nilai $R$-square untuk actual system use sebesar 0,467. Hal ini menunjukan bahwa 45,6\% actual system use dapat dijelaskan oleh perceived ease of use, perceived usefulness, dan minat menggunakan, dan sisanya sebesar 54,4\% dapat dijelaskan oleh faktor lain.

Nilai $R$-square untuk minat menggunakan sebesar 0,069. Hal ini menunjukan bahwa 6,9\% minat menggunakan dapat dijelaskan oleh perceived ease of use, perceived usefulness, dan sisanya sebesar $93,1 \%$ dapat dijelaskan oleh faktor lain.

\section{Uji Hipotesis}

Uji Hipotesis Berdasarkan olah data yang dilakukan oleh peneliti dapat digunakan untuk menjawab hipotesis penelitian ini. Berikut adalah hasil yang diperoleh dalam uji hipotesis pada model penelitian dengan melihat nilai T-Statistics dan nilai $P$-Values. Dengan nilai T-Statistics $>1,65$ dan nilai P-Values $<0,1$ sebagai berikut:

Tabel 5. Evaluasi Model Struktural

\begin{tabular}{|l|c|c|c|}
\hline & $\begin{array}{c}\text { T- } \\
\text { Statistic } \\
\text { (O/STA } \\
\text { DEV) }\end{array}$ & $\begin{array}{c}\text { P- } \\
\text { Valu } \\
\text { es }\end{array}$ & $\begin{array}{c}\text { Pengaru } \\
\text { h } \\
\text { (Persent } \\
\text { ase) }\end{array}$ \\
\hline PEoU (XI) -> ASU (Y) & 6,632 & $\begin{array}{c}0,00 \\
0\end{array}$ & $36,7 \%$ \\
\hline PU (X2 -> ASU (Y) & 6,133 & $\begin{array}{c}0,00 \\
0\end{array}$ & $34,1 \%$ \\
\hline PEoU (X1) -> MM (M) & 4,483 & $\begin{array}{c}0,00 \\
0\end{array}$ & $25,5 \%$ \\
\hline PU (X2) -> MM (M) & 0,586 & $\begin{array}{c}0,27 \\
9\end{array}$ & $3 \%$ \\
\hline
\end{tabular}


Uswatun Hasanah et al

\begin{tabular}{|l|c|c|c|}
\hline $\mathrm{MM}(\mathrm{M})$-> ASU (Y) & 6,609 & $\begin{array}{c}0,00 \\
0\end{array}$ & $29,2 \%$ \\
\hline $\begin{array}{l}\text { Intervening XI->M } \\
\text {-> ASU (Y) }\end{array}$ & 3,399 & $\begin{array}{c}0,00 \\
0\end{array}$ & $7,5 \%$ \\
\hline $\begin{array}{l}\text { Intervening X2->M } \\
\text {-> ASU (Y) }\end{array}$ & 0,586 & $\begin{array}{c}0,27 \\
9\end{array}$ & $0,9 \%$ \\
\hline
\end{tabular}

Sumber: Data Olahan SmartPLS, 2021

\section{Pengaruh Perceived Ease of Use terhadap Actual System Use}

Perceived ease of use dihipotesiskan mempengaruhi actual system use. Berikut ini hasil uji signifikansi dari hipotesis tersebut melalui hipotesis statistik:

Tabel 5. Hasil Pengujian Pengaruh Perceived Ease of Use terhadap Actual System Use

\begin{tabular}{|l|c|c|}
\hline & $\begin{array}{c}\text { T-Statistic } \\
\text { (O/STADEV) }\end{array}$ & $\begin{array}{c}\text { P- } \\
\text { Values }\end{array}$ \\
\hline $\begin{array}{l}\text { PEoU (XI) -> ASU } \\
\text { (Y) }\end{array}$ & 6,632 & 0,000 \\
\hline \multicolumn{2}{|c|}{ Sumber: Data Olahan SmartPLS, 2021} \\
\hline
\end{tabular}

Berdasarkan tabel 5 dapat dilihat hubungan antara perceived ease of use dengan actual system use adalah signifikan dengan $t$-statistic 6,632 (thitung lebih dari 1,65) dan nilai P-Values sebesar $0,000<0,1$. Dapat disimpulkan bahwa Perceived Ease ot Use berpengaruh positif dan signifikan terhadap Actual System Use.

\section{Pengaruh Perceived Usefulness terhadap Actual System Use}

Perceived usefulness dihipotesiskan mempengaruhi actual system use. Berikut ini hasil uji signifikansi dari hipotesis tersebut melalui hipotesis statistik:

Tabel 6. Hasil Pengujian Pengaruh Perceived Usefulness terhadap Actual System Use

\begin{tabular}{|l|c|c|}
\hline & $\begin{array}{c}\text { T-Statistic } \\
\text { (O/STADEV) }\end{array}$ & $\begin{array}{c}\text { P- } \\
\text { Values }\end{array}$ \\
\hline PU (X2) -> ASU (Y) & 4,483 & 0,000 \\
\hline
\end{tabular}

Sumber: Data Olahan SmartPLS, 2021
Berdasarkan tabel 6 dapat dilihat hubungan antara perceived usefulness dengan actual system use adalah signifikan dengan $t$-statistic 6,133 (thitung lebih dari 1,65) dan nilai P-Values sebesar $0,000<0,1$. Dapat disimpulkan bahwa perceived usefulness berpengaruh positif dan signifikan terhadap actual system use.

\section{Pengaruh Perceived Ease of Use terhadap Minat Menggunakan}

Perceived ease of use dihipotesiskan mempengaruhi minat menggunakan. Berikut ini hasil uji signifikansi dari hipotesis tersebut melalui hipotesis statistik:

Tabel 7. Hasil Pengujian Pengaruh Perceived Ease of Use terhadap Minat Menggunakan

\begin{tabular}{|c|c|c|}
\hline & $\begin{array}{c}\text { T-Statistic } \\
\text { (O/STADEV) }\end{array}$ & $\begin{array}{c}\text { P- } \\
\text { Values }\end{array}$ \\
\hline PEoU (XI) -> MM (M) & 6,133 & 0,000 \\
\hline
\end{tabular}

Sumber: Data Olahan SmartPLS, 2021

Berdasarkan tabel 7 dapat dilihat hubungan antara perceived ease of use dengan minat menggunakan adalah signifikan dengan $t$-statistic 4,483 (t-hitung lebih dari 1,65) dan nilai P-Values sebesar 0,001 < 0,1. Dapat disimpulkan bahwa perceived ease ot use berpengaruh positif dan signifikan terhadap minat menggunakan.

\section{Pengaruh Perceived Usefulness terhadap Minat Menggunakan}

Perceived usefulness dihipotesiskan mempengaruhi minat menggunakan. Berikut ini hasil uji signifikansi dari hipotesis tersebut melalui hipotesis statistik: 
Tabel 8. Hasil Pengujian Pengaruh Perceived Usefulness terhadap Minat Menggunakan

\begin{tabular}{|l|c|c|}
\hline & $\begin{array}{c}\text { T-Statistic } \\
\text { (O/STADEV) }\end{array}$ & $\begin{array}{c}\text { P- } \\
\text { Values }\end{array}$ \\
\hline PU (X2) -> MM (M) & 0,586 & 0,279 \\
\hline
\end{tabular}

Sumber: Data Olahan SmartPLS, 2021

Berdasarkan tabel 9 dapat dilihat hubungan antara perceived usefulness dengan minat menggunakan adalah tidak signifikan dengan $t$ statistic 0,86 (t-hitung kurang dari 1,65) dan nilai PValues sebesar 0,279>0,1. Dapat disimpulkan bahwa perceived usefulness tidak berpengaruh terhadap minat menggunakan.

\section{Pengaruh Minat Menggunakan terhadap Actual System Use}

Minat menggunakan dihipotesiskan mempengaruhi actual system use. Berikut ini hasil uji signifikansi dari hipotesis tersebut melalui hipotesis statistik:

Tabel 10. Hasil Pengujian Pengaruh Minat Menggunakan terhadap Actual System Use

\begin{tabular}{|l|c|c|}
\hline & $\begin{array}{c}\text { T-Statistic } \\
\text { (O/STADEV) }\end{array}$ & $\begin{array}{c}\text { P- } \\
\text { Values }\end{array}$ \\
\hline $\begin{array}{l}\text { MM (M) -> ASU } \\
(\mathrm{Y})\end{array}$ & 6,609 & 0,000 \\
\hline
\end{tabular}

Sumber: Data Olahan SmartPLS, 2021

Berdasarkan tabel 10 dapat hubungan antara minat menggunakan dengan actual system use adalah signifikan dengan $t$-statistic 6,609 (t-hitung lebih dari 1,65) dan nilai P-Values sebesar 0,000 < 0,1 . Dapat disimpulkan bahwa minat menggunakan berpengaruh positif dan signifikan terhadap actual system use.

\section{Pengaruh Perceived Ease of Use terhadap Actual System Use dengan Minat Menggunakan sebagai Variabel Intervening}

Perceived ease of use dihipotesiskan mempengaruhi actual system use dengan minat menggunakan sebagai variabel intervening. Berikut ini hasil uji signifikansi dari hipotesis tersebut melalui hipotesis statistik:

Tabel 11. Hasil Pengujian Pengaruh Perceived Ease Of Use terhadap Actual System Use dengan Minat Menggunakan sebagai Variabel Intervening

\begin{tabular}{|l|c|c|}
\hline & $\begin{array}{c}\text { T-Statistic } \\
\text { (O/STADEV) }\end{array}$ & $\begin{array}{c}\text { P- } \\
\text { Values }\end{array}$ \\
\hline $\begin{array}{l}\text { Intervening XI->M } \\
\rightarrow \text { ASU (Y) }\end{array}$ & 3,399 & 0,000 \\
\hline
\end{tabular}

Sumber: Data Olahan SmartPLS, 2021

Berdasarkan tabel 11 menunjukkan bahwa perceived ease of use berpengaruh positif dan signifikan terhadap actual system use dengan minat menggunakan sebagai variabel intervening. Ditunjukan dengan t-statistik 3,399 (t-hitung lebih dari 1,65) dan P-Values sebesar 0,000 <0,1.

\section{Pengaruh Perceived Usefulness terhadap Actual System Use dengan Minat Menggunakan sebagai Variabel Intervening}

Perceived usefulness dihipotesiskan mempengaruhi actual system use dengan minat menggunakan sebagai variabel intervening. Berikut ini hasil uji signifikansi dari hipotesis tersebut melalui hipotesis statistik

Tabel 12. Hasil Pengujian Pengaruh Perceived Usefulness terhadap Actual System Use dengan Minat Menggunakan sebagai Variabel Intervening

\begin{tabular}{|l|c|c|}
\hline & $\begin{array}{c}\text { T-Statistic } \\
\text { (O/STADEV) }\end{array}$ & $\begin{array}{c}\text { P- } \\
\text { Values }\end{array}$ \\
\hline $\begin{array}{l}\text { Intervening X2->M } \\
->\text { ASU (Y) }\end{array}$ & 0,586 & 0,279 \\
\hline
\end{tabular}


Sumber: Data Olahan SmartPLS, 2021

Berdasarkan tabel 12 menunjukkan bahwa perceived usefulness tidak berpengaruh terhadap actual system use dengan minat menggunakan sebagai variabel intervening. Ditunjukan dengan tstatistik 0,586 (t-hitung kurang dari 1,65) dan PValues sebesar 0,279>0,1.

\section{Pembahasan Hasil Penelitian}

Dalam pengujian hipotesis, nilai yang dianalisa adalah nilai yang ada pada $t$-statistic yang dihasilkan dari output PLS dengan membandingkan t-tabel. Output PLS merupakan estimasi variabel laten yang merupakan linier agregat dari indikator. Keriteria pengujian dengan tingkat signifikansi $(\alpha)$ 10\%. Hipotesis yang digunakan adalah sebagai berikut:

a. Apabila t-hitung $>$ dari t-tabel yaitu lebih dari 1.65, maka hipotesis diterima.

b. Apabila t-hitung > dari t-tabel yaitu kurang dari 1.65, maka hipotesis ditolak.

Pengujian hipotesis dengan PLS dilakukan dua tahap, yakni menghitung langsung pengaruh variabel laten independen terhadap varabel laten dependen, dan menghitung pengaruh laten independen terhadap variabel laten dependen dengan peintervensi.

\section{Pengujian Hipotesis 1: Pengaruh Langsung Perceived Ease of Use terhadap Actual System Use}

Hipotesis ke-1 yang menguji hubungan antara perceived ease of use dengan actual system use adalah signifikan dengan nilai t-statistik 6,632 (t-hitung lebih dari 1,65) dan nilai P-Values sebesar $0,000<0,1$. Dapat disimpulkan bahwa perceived ease of use berpengaruh terhadap actual system use. Maka hipotesis pertama dalam penelitian ini diterima. Dari hasil data tersebut, dapat interpretasikan bahwa data sampel variabel laten independen (perceived ease of use) berhasil membuktikan hubungan dengan variabel laten dependen (actual system use), atau dengan kata lain XI memberikan pengaruh signifikan terhadap Y.

Perceived ease of use memberikan pengaruh secara langsung terhadap actual system use sebesar $36,7 \%$. Semakin tinggi kemudahan penggunaan sistem layanan syariah linkaja maka akan semakin tinggi penggunaan aktualnya, begitupun sebaliknya, semakin rendah kemudahan penggunaan sistem layanan syariah linkaja maka semakin rendah pula penggunaan aktualnya.

Hasil penelitian yang menyatakan bahwa perceived ease of use berpengaruh terhadap actual system use diperkuat oleh teori TAM (Technology Acceptane Model) oleh Davis yang menyatakan bahwa perceived ease of use adalah salah satu unsur yang terpenting dalam membangun integrasi teknologi. Jika teknologi tersebut mudah digunakan, maka terjadi penggunaan aktual.

Penelitian ini sejalan dengan penelitian yang dilakukan Ricky Aditya dan Aditya Wardana yang mengkaji tentang pengaruh perceived usefulness dan perceived ease of use terhadapa behavioural intention dengan pendekatan Technology Acceptane Model (TAM) pada pengguna instant messaging LINE di Indonesia. Dan penelitian yang dilakukan oleh Rila Anggraini yang membahas mengenai pengaruh persepsi kemudahan penggunaan, persepsi kegunaan terhadap minat untuk menggunakan dan penggunaan aktual layanan jejaring berbasis lokasi yang dilaksanakan di Universitas Brawijaya dengan populasi mahasiswa (Anggraeni, 2015).

Berdasarkan hasil yang telah dilakukan, maka dapat disimpulkan bahwa responden berupa masyarakat merasakan kemudahan penggunaan dari layanan syariah linkaja sehingga menimbulkan penggunaan aktual yang berarti masyarakat mampu menerima layanan syariah linkaja dengan baik. 
Pengujian Hipotesis 2: Pengaruh Langsung Perceived Usefulness Terhadap Actual System Use

Hipotesis ke-2 yang menguji hubungan antara pengaruh langsung perceived usefulness terhadap actual system use adalah signifikan dengan t-statistik 4,483 (t-hitung lebih dari 1,65) dan nilai P-Values sebesar $0,000<0,1$. Dapat disimpulkan bahwa perceived usefulness berpengaruh terhadap actual system use. Maka hipotesis kedua dalam penelitian ini diterima. Dari hasil data tersebut, dapat diinterpretasikan bahwa data sampel variabel independen (perceived usefulness) berhasil membuktikan hubungan antara variabel dependen (actual system use) atau dengan kata lain X2 menberikan pengaruh signifikan terhadap Y.

Perceived usefulness memberikan pengaruh secara langsung terhadap actual system use sebesar $34,1 \%$. Semakin tinggi manfaat layanan syariah linkaja maka akan semakin tinggi penggunaan aktualnya, begitupun sebaliknya, semakin rendah manfaat layanan syariah linkaja maka semakin rendah pula penggunaan aktual.

Hasil penelitian yan menyatakan bahwa perceived usefulness berpengaruh terhadap actual system use diperkuat oleh teori TAM (Technology Acceptane Model) oleh Davis yang menyatakan bahwa perceived usefulness adalah salah satu unsure yang terpenting dalam membangun integrasi teknologi. Jika teknologi tersebut bermanfaat, maka terjadi penggunaan aktual.

Hasil penalitian ini sejalan dengan penelitian yang dilakukan oleh mega purwitasari dan dudi pratomo yang membahas mengenai pengaruh perceived usefulness dan perceived ease of use terhadap actual system use (efisinsi pengisian spt) menurut persepsi wajib pajak. penelitian ini dilakukan pada KPP Pratama Bandung
Cibeunying. Hasil penelitiannya menyatakan bahwa perceived usefulness berpengaruh terhadap actual system use (Purwitasari \& Pratomo, 2015). Dan penelitian yang dilakukan oleh Putu Ayu Mira Witriyani Wida, et.al yang membahas tentang aplikasi model TAM (Technology Acceptance Model) pada perilaku pengguna instagram. Hasil penelitiannya menyatakan bahwa perceived usefulness berpengaruh terhadap actual system use (Wida et al., 2016).

Berdasarkan hasil yang telah dilakukan, maka dapat disimpulkan bahwa responden berupa masyarakat merasakan manfaat dari layanan syariah linkaja sehingga menimbulkan penggunaan aktual yang berarti masyarakat mampu menerima layanan syariah linkaja dengan baik. Meskipun manfaat layanan syariah linkaja telah dirasakan oleh masyarakat sehingga menimbulkan penggunaan aktual, perusahaan PT. Fintek Karya Nusantara harus tetap meningkatkan kredibilitas dan kecanggihan aplikasi serta pelayanan yang memberikan manfaat agar mampu meningkatkan penggunaan aktual masyarakat.

\section{Pengujian Hipotesis 3: Pengaruh Perceived Ease of Use terhadap Minat Menggunakan}

Hipotesis ke-3 yang menguji hubungan antara perceived ease of use dengan minat menggunakan adalah signifikan dengan nilai tstatistik 6,133 (t-hitung lebih dari 1,65) dan nilai $P$ vales sebesar $0,000<0,1$. Dapat disimpulkan perceived ease of use bahwa berpengaruh terhadap minat menggunakan. Maka hipotesis ketiga dalam penelitian diterima. Dari hasil data tersebut, dapat diinterpretasikan bahwa data sampel variabel laten independen (perceived ease of use) berhasil membuktikan hubungan dengan variabel $\mathrm{M}$ (minat menggunakan) atau dengan kata lain X2 memberikan pengaruh terhadap $\mathrm{M}$. 
Perceived ease of use memberikan pengaruh secara langsung terhadap minat menggunakan sebesar 25,5\%. Semakin tinggi kemudahan penggunaan layanan syariah, maka akan semakin tinggi pula minat seseorang dalam menggunakannya, begitupun sebaliknya, semakin rendah kemudahan penggunaan layanan syariah linkaja maka semakin rendah pula minat seseorang dalam menggunakannya.

Hasil penelitian yang menyatakan bahwa perceived ease of use berpengaruh terhadap minat diperkuat oleh teori TAM (Technology Acceptane Model) oleh Davis yang menyatakan bahwa perceived easy of use adalah salah satu unsur yang terpenting dalam membangun integrasi teknologi dalam membentuk minat seseorang untuk menggunakan teknologi tersebut.

Penelitian ini sejalan dengan penelitian yang dilakukan Ricky Aditya dan Aditya Wardana yang mengkaji tentang pengaruh perceived usefulness dan perceived ease of use terhadap minat menggunakan dengan pendekatan Technology Acceptane Model (TAM) pada pengguna instant messaging LINE di Indonesia. Penelitian yang dilakukakan Istiarni, et.al. yang membahas tentang analisis pengaruh persepsi manfaat, kemudahan penggunaan, dan kredibilitas terhadap minat penggunaan berulang internet banking dengan sikap penggunaan sebagai variabel intervening (Istiarni, 2014).

Dan penelitian yang dilakukan oleh Rila Anggraini (2015) yang membahas mengenai pengaruh persepsi kemudahan penggunaan, persepsi kegunaan terhadap minat untuk menggunakan dan penggunaan aktual layanan jejaring berbasis lokasi yang dilaksanakan di Universitas Brawijaya dengan populasi mahasiswa. penelitian yang dilakukan oleh Saleh Al-Harbi yang mengkaji tentang menggunakan model penerimaan teknologi dalam memahami minat perilaku akademik untuk menggunakan sistem manajemen pemebelajaran membahas tentang e-learning. Hasil penelitiannya menyatakan bahwa perceived ease of use berpengaruh terhadap minat menggunakan (Alharbi \& Drew, 2014).

Dan penelitian yang dilakukan oleh endang Fatmawati yang mengkaji tentang system informasi dalam perpustakaan yang bertujuan untuk melihat sikap pengguna dalam penerimaan teknologi Hasil penelitiannya menyatakan bahwa perceived ease of use berpengaruh terhadap minat menggunakan (Fatmawati, 2015).

Berdasarkan hasil penelitian yang telah dilakukan, maka dapat disimpulkan bahwa responden berupa masyarakat merasakan kemudahan penggunaan dari layanan syariah linkaja sehingga menimbulkan minat penggunaan yang berarti masyarakat mampu menerima layanan syariah linkaja dengan baik.

\section{Pengujian Hipotesis 4: Pengaruh Perceived Usefulness terhadap Minat Menggunakan}

Hipotesis ke-4 yang menguji hubungan antara perceived usefulness dengan minat menggunakan adalah tidak signifikan dengan tstatistik 0,586 (t-hitung kurang dari 1,65) dan nilai $P$-vales sebesar 0,279>0,1. Dapat disimpulkan bahwa perceived usefulness tidak berpengaruh terhadap minat menggunakan. Maka hipotesis keempat ditolak.

Perceived usefulness tidak berpengaruh terhadap minat penggunaan. Ketidaksignifikan ini jika dilihat dari distribusi jawaban responden (Tabel 4.6) jawaban pernyataan PU1.1 dengan jawaban tidak setuju (skala 2) sebanyak 4 responden dan jawaban sangat tidak setuju (skala 1) sebanyak 5 responden. Pernyataan PU1.2 dengan jawaban tidak setuju (skala 2) sebanyak 9 responden. 
Pernyataan PU2.1 dengan jawaban tidak setuju (skala 2) sebanyak 4 responden. Pernyataan PU2.2 dengan jawaban tidak setuju (skala 2) sebanyak 3 responden dan jawaban sangat tidak setuju (skala 1) sebanyak 5 responden. Pernyataan PU3.1 dengan jawaban tidak setuju (skala 2) sebanyak 3 responden dan jawaban sangat tidak setuju (skala 1) sebanyak 4 responden. Pernyataan PU3.2 dengan jawaban tidak setuju (skala 2) sebanyak 3 responden dan jawaban sangat tidak setuju (skala 1) sebanyak 5 responden. Pernyataan PU4.1 dengan jawaban tidak setuju (skala 2) sebanyak 7 responden dan jawaban sangat tidak setuju (skala 1) sebanyak 2 responden. Pernyataan PU4.2 dengan jawaban tidak setuju (skala 2) sebanyak 6 responden. Pernyataan PU5.1 dengan jawaban tidak setuju (skala 2) sebanyak 7 responden dan jawaban sangat tidak setuju (skala 1) sebanyak 4 responden. Pernyataan PU5.2 dengan jawaban tidak setuju (skala 2) sebanyak 3 responden dan jawaban sangat tidak setuju (skala 1) sebanyak 2 responden.

Perceived usefulness memberikan pengaruh secara langsung terhadap minat menggunakan hanya sebesar 3\%. Semakin rendah manfaat layanan syariah linkaja maka semakin rendah pula minat seseorang dalam menggunakannya.

Penelitian yang menyatakan bahwa bahwa perceived usefulness tidak berpengaruh terhadap minat menggunakan adalah Feronica Mayasari, et.al yang mengkaji tentang anteseden dan konsekuen sikap nasabah dalam menggunakan internet banking dengan menggunakan kerangka technology acceptance model (TAM) yang membahas mengenai penggunaan internet banking berdasarkan panduan. Hasil penelitiannya menyatakan bahwa perceived usefulness tidak berpengaruh terhadap minat menggunakan (Mayasari et al., 2011).
Berdasarkan hasil penelitian yang telah dilakukan maka dapat disimpulkan responden berupa masyarakat kurang merasakan manfaat dari layanan syariah linkaja sehingga menimbulkan kurang minatnya terhadap penggunaan layanan syariah linkaja yang berarti bahwa masyarakat kurang mampu menerima layanan syariah linkaja dengan baik. Perusahaan PT. Fintek Karya Nusantara harus lebih meningkatkan kredibilitas dan kecanggihan aplikasi serta pelayanan yang memberikan manfaat agar mampu meningkatkan minat penggunaan masyarakat dalam menggunakan layanan syariah linkaja di kota Palembang.

\section{Pengujian Hipotesis 5: Pengaruh Minat Menggunakan terhadap Actual System Use}

Hipotesis ke-5 menguji hubungan antara minat menggunakan dengan actual system use adalah signifikan dengan nilai t-statistik 6,609 (thitung lebih dari 1,65) dan nilai P-Values $0,000<$ 0,1 . Dapat simpulkan bahwa minat menggunakan berpengaruh terhadap actual system use. Maka hipotesis kelima dalam penelitian diterima. Dari hasil data tersebut diinterpretasikan bahwa data sampel variabel laten $M$ (minat menggunakan) berhasil membuktikan hubungan dengan variabel dependen (actual system use) atau dengan kata lain M memberikan pengaruh terhadap terhadap Y.

Minat menggunakan memberikan pengaruh secara langsung terhadap actual system use sebesar $29,2 \%$. Semakin tinggi minat menggunakan sistem layanan syariah linkaja maka akan semakin tinggi penggunaan aktualnya, begitupun sebaliknya, semakin rendah minat menggunakan sistem layanan syariah linkaja maka semakin rendah pula penggunaan aktualnya.

Hasil penelitian ini diperkuat oleh teori TAM (Technology Acceptance Model) oleh davis yang 
menyatakan bahwa sebelum memutuskan untuk menggunakan teknologi. Hasil penelitian ini juga didukung oleh Theory of Reasoned Action yang diperkenalkan oleh Fishbein dan Ajzen. Teori ini menyatakan bahwa pengguaan aktual timbul karena adanya minat penggunaan (Mahyarni, 2013).

Hasil penelitian ini sejalan dengan penelitian yang dilakukan oleh Joni Hendra dan Ahmad Iskandar yang membahas mengenai aplikasi model TAM terhadap pengguna layanan internet banking di kantor bank jatim yang berlokasi di Situbondo (Hendra \& Iskandar, 2016) dan penelitian yang dilakukan oleh Aditya Arie Hanggono (2015) yang mengkaji tentang Analisis atas Praktik TAM (Technology Acceptance Model) dalam Mendukung Bisnis Online dengan Memanfaatkan Jejaring Sosial Instagram. Hasil penelitinnya menyatakan bahwa minat menggunakan berpengaruh terhadap actual system use.

\section{Pengujian Hipotesis 6: Pengaruh Perceived Ease of Use Terhadap Actual System Use Melalui Minat Menggunakan}

Hasil pengujian hipotesis keenam menunjukkan bahwa perceived ease of use berpengaruh terhadap actual system use melalui minat menggunakan. Ditunjukan dengan t-statistik 3,399 (t-hitung lebih dari 1,65) dan P-Values sebesar $0,000<0,1$. Maka hipotesis keenam dalam penelitian ini diterima, dan memiliki pengaruh yang signifikan sebesar $7,5 \%$. Semakin tinggi kemudahan penggunaan sistem serta minat penggunaan layanan syariah linkaja maka akan semakin tinggi penggunaan aktualnya, begitu sebaliknya, semakin rendah kemudahan penggunaan sistem serta minat penggunaan layanan syariah linkaja maka akan semakin rendah pula penggunaan aktualnya.
Hasil penelitian ini diperkuat oleh teorti TAM (Technology Acceptance Model) oleh Davis yang menyatakan bahwa kemudahan menggunaan memicu minat seseorang untuk menggunakan sehingga menimbulkan penggunaan yang aktual. Hasil penelitian ini juga didukung oleh Theory of Reasoned Action yang diperkenalkan oleh Fishbein dan Ajzen. Teori ini menyatakan bahwa pengguaan aktual timbul karena adanya minat penggunaan (Mahyarni, 2013).

Penelitian yang menyatakan bahwa variabel antara perceived ease of use dengan actual system use melalui minat menggunakan memiliki pengaruh adalah penelitian yang dilakukan Rila Anggraini (2015) yang membahas tentang Pengaruh Persepsi Kemudahan Penggunaan dan Persepsi Kegunaan terhadap Niat untuk Menggunakan dan Penggunaan Actual Layanan Jejaring Soaial Berbasis Lokasi dan Aditya Arie Hanggono (2015) yang membahas tentang Analisis atas Praktik TAM (Technology Acceptance Model) dalam Mendukung Bisnis Online dengan Memanfaatkan Jejaring Sosial Instagram.

Berdasarkan hasil penelitian yang telah dilakukan, maka dapat disimpulkan bahwa responden berupa masyarakat merasakan kemudahan penggunaan layanan syariah linkaja sehingga menimbulkan minat untuk menggunakan yang kemudian berdampak terhadap penggunaan aktual. Meskipun demikian, hubungan kemudahan terhadap penggunaan aktual melalui minat menggunakan tetap harus meningkatkan kualitas khususnya kemudahan akses dan pelayanan agar mampu meningkatkan penggunaan aktual masyarakata di kota Palembang melalui minat menggunakan.

\section{Pengujian Hipotesis 7: Pengaruh Perceived Usefulness terhadap Actual System Use Melalui Minat Menggunakan}


Model penelitian juga menunjukkan adanya pengaruh tidak langsung di antara variabel-variabel penelitian. Hipotesis ketujuh dari Hasil pengujian data menunjukkan bahwa nilai t-statistik sebesar 0,586 (t-hitung kurang dari 1,65) dan nilai P-Values sebesar 0,279>0,1, karena nilai t-statistik lebih kecil dibanding t-hitung maka dengan tingkat signifikansi diatas 0,1 yaitu 0,279 diputuskan untuk menolak H7. Jadi berdasarkan hasil pengujian menunjukkan bahwa perceived usefulness tidak berpengaruh terhadap actual system use dengan minat menggunakan sebagai variabel intervening. Dengan pengaruh sebesar $0,9 \%$. Semakin rendah manfaat sistem serta minat penggunaan layanan syariah linkaja maka akan semakin rendah pula penggunaan aktualnya.

Pada penelitian ini hasil pengujian pengaruh perceived usefulness secara langsung tidak berpengaruh terhadap minat menggunakan dengan nilai t-statistik sebesar $0,586<1,65$ dan nilai-p sebesar 0,279>0,1, sedangkan pengujian pengaruh tidak langsung antara perceived usefulness terhadap actual system use melalui minat menggunakan sebagai variabel intervening juga membuktikan bahwa minat menggunakan tidak dapat menjadi variabel intervening pengaruh perceived usefulness terhadap actual system use dengan nilai t-statistik sebesar 0,856 < 1,65 dan nilai-p sebesar 0,279>0,1. Hal ini menunjukkan bahwa perceived usefulness tidak berpengaruh terhadap actual system use dengan minat menggunakan sebagai variabel intervening. Hal ini artinya bahwa penggunaan minat menggunakan sebagai variabel intervening belum tepat dan kurang mendukung adanya pengaruh perceived usefulness terhadap actual system use sehingga untuk meningkatkan actual system use akan lebih baik mungkin dengan melalui variabel intervening yang lain, yang mungkin akan diteliti oleh peneliti selanjutnya.
Sejalan dengan hasil penelitian yang menyatakan bahwa variabel antara perceived usefulness dengan actual system use melalui minat menggunakan tidak memiliki pengaruh adalah penelitian Mega Purwita dan Dudi Pratomo (2015) yang membahas tentang Pengaruh Perceived Usefulness Dan Perceived Ease Of Use Terhadap Actual System Usage (Efisiensi Pengisian Spt) Menurut Persepsi Wajib Pajak (Survey terhadap Pengusaha Kena Pajak pada KKP Pratama Bandung Cibeunying).

Berdasarkan hasil penelitian yang telah dilakukan, maka dapat disimpulkan bahwa responden berupa masyarakat kurang merasakan manafaat penggunaan layanan syariah linkaja sehingga menimbulkan kurang minatnya untuk menggunakan yang kemudian berdampak terhadap penggunaan aktual, Maka hubungan manfaat terhadap penggunaan aktual melalui minat menggunakan tetap harus meningkatkan kualitas khususnya pelayanan agar mampu meningkatkan penggunaan aktual masyarakata di kota Palembang melalui minat menggunakan.

\section{Kesimpulan}

Penelitian ini menyimpulkan bahwa pertama, variabel perceived ease of use berpengaruh positif dan signifikan terhadap actual system use. Artinya pengguna layanan syariah linkaja mempersepsikan bahwa kemudahan penggunaan aplikasi akan menyebabkan mereka menggunakan layanan syariah linkaja. Kedua, variabel perceived usefulness berpengaruh positif dan signifikan terhadap actual system use. Artinya pengguna layanan syariah linkaja mempersepsikan bahwa manfaat aplikasi akan menyebabkan mereka menggunakan layanan syariah linkaja. Ketiga, variabel perceived ease of use berpengaruh positif dan signifikan terhadap minat menggunakan. Artinya pengguna layanan syariah linkaja 
mempersepsikan bahwa kemudahan penggunaan aplikasi akan menyebabkan mereka minat menggunakan layanan syariah linkaja. Keempat, variabel perceived usefulness tidak berpengaruh terhadap minat menggunakan. Artinya pengguna layanan syariah linkaja mempersepsikan bahwa manfaat aplikasi tidak bisa menyebabkan mereka untuk minat menggunakan layanan syariah linkaja. Kelima, variabel minat menggunakan berpengaruh positif dan signifikan terhadap actual system use. Artinya pengguna layanan syariah linkaja mempersepsikan bahwa minat menggunakan aplikasi akan menyebabkan mereka menggunakan layanan syariah linkaja. Keenam, perceived ease of use berpengaruh positif dan signifikan terhadap actual system use melalui minat menggunakan. Artinya pengguna mempersepsikan bahwa kemudahan penggunaan aplikasi dapat menimbulkan minat yang akhirnya membuat mereka menggunakan aplikasi tersebut. Dan ketujuh, perceived usefulness tidak berpengaruh terhadap actual system use melalui variabel minat menggunakan. Artinya pengguna mempersepsikan manfaat dari aplikasi layanan syariah linkaja langsung menyebabkan mereka menjadi pengguna tanpa menimbulkan minat terlebih dahulu.

\section{Daftar Pustaka}

Alharbi, S., \& Drew, S. (2014). Using the Technology Acceptance Model in Understanding Academics' Behavioural Intention to Use Learning Management Systems. International Journal of Advanced Computer Science and Applications, 5(1), 143-155.

https://doi.org/10.14569/ijacsa.2014.050120

Anggraeni, R. (2015). Pengaruh Persepsi Kemudahan Penggunaan Dan Persepsi Kegunaan Terhadap Niat Untuk Menggunakan Dan Penggunaan Aktual Layanan Jejaring Sosial Berbasis Lokasi (Studi Pada Mahasiswa Fakultas Ekonomi Dan Bisnis Universitas Brawijaya Malang). Ekonomi Bisnis, 20(1), 44-52. https://doi.org/10.17977/um042v20i1p44-52

Budiastuti, A. D. P., \& Muid, D. (2020). Analisis

Faktor-Faktor Pengaruh Minat Penggunaan

Pada Aplikasi Shopee Dengan Menggunakan

Technology Acceptance Model ( Tam ). Diponegoro Journal of Accounting, 9(4), 1-

10.

s1.undip.ac.id/index.php/accounting

Davis, F. D. (1989). Perceived Usefulness, Perceived Ease of Use, and User Acceptance of Information Technology. MIS Quarterly, 13(3), 319. https://doi.org/10.2307/249008

Fatmawati, E. (2015). Technology Acceptance Model (TAM) Untuk Menganalisis Sistem Informasi Perpustakaan. Iqra': Jurnal Perpustakaan Dan Informasi, 9(1), 1-13. http://jurnal.uinsu.ac.id/index.php/iqra/article/ view/66

Hanggono, A. (2015). Analisis Atas Praktek Tam (Technology Acceptance Model) Dalam Mendukung Bisnis Online Dengan Memanfaatkan Jejaring Sosial Instagram. Jurnal Administrasi Bisnis S1 Universitas Brawijaya, 26(1), 86245.

Hendra, J., \& Iskandar, A. (2016). Aplikasi Model TAM Terhadap Pengguna Layanan Internet Banking di Kantor Bank Jatim Cabang Situbondo. Jurnal Ecobuss, 4(1), 40-48. www.bi.go.id

Istiarni. (2014). ANALISIS PENGARUH PERSEPSI MANFAAT, KEMUDAHAN PENGGUNAAN DAN KREDIBILITAS TERHADAP MINAT PENGGUNAAN BERULANG INTERNET BANKING DENGAN SIKAP PENGGUNAAN SEBAGAI VARIABEL INTERVENING (Studi Empiris: Nasabah Layanan Internet Banking di Indonesia). Diponegoro Journal of Accounting, 3(2), 888-897.

Mahyarni, M. (2013). THEORY OF REASONED ACTION DAN THEORY OF PLANNED BEHAVIOR (Sebuah Kajian Historis tentang Perilaku). Jurnal EL-RIYASAH, 4(1), 13. https://doi.org/10.24014/jel.v4i1.17

Mayasari, F., Kurniawati, E., \& Nugroho, P. (2011). ANTESEDEN DAN KONSEKUEN SIKAP NASABAH DALAM MENGGUNAKAN INTERNET BANKING DENGAN MENGGUNAKAN KERANGKA TECHNOLOGY ACCEPTANCE MODEL (TAM) (SURVEY 
PADA PENGGUNA KlikBCA). Semantik, l(1).

Muflihhadi, I., \& Rubiyanti, R. N. (2016). Pengaruh Perceived Usefulness, Perceived Ease of Use , Dan Trust Terhadap Kepuasan Konsumen ( Studi Pada Gojek Bandung ) the Impact of Perceived Usefulness, Perceived Ease of Use , and Trust in Custome Rs ' Satisfaction ( Case Study in Gojek Bandung ). E-Proceeding of Management, 3(2), 2026-2033.

Permana, P. A. (2018). Analisis Technology Acceptance Model ( TAM ) pada Sistem Informasi KIPEM ( Studi Kasus: Banjar Delodpasar, Desa Blahkiuh Bali ). Journal Speed-Sentra Penelitian Engineering Dan Edukasi, 10(4), 28-37.

Purwitasari, M., \& Pratomo, D. (2015). PENGARUH PERCEIVED USEFULNESS DAN PERCEIVED EASE OF USE TERHADAP ACTUAL SYSTEM USAGE (EFISIENSI PENGISIAN SPT) MENURUT PERSEPSI WAJIB PAJAK (Survey Terhadap Pengusaha Kena Pajak Pada KPP Pratama Bandung Cibeunying). E-Proceeding of Management, 2(3), 3213.

Wida, P., Yasa, N., \& Sukaatmadja, I. (2016). Aplikasi Model Tam (Technology Acceptance Model)Pada Perilaku Pengguna Instagram. Jurnal Ilmu Manajemen Mahasaraswati, 6(2), 101948. 